\title{
The Development of Modeling Physics Learning to Improve Critical Thinking Ability of Student
}

\author{
Muhammad Arifuddin ${ }^{1 *}$, Syamsul Bachri Talib ${ }^{2}$, Jasruddin ${ }^{3}$, Muhammad Sidin Ali ${ }^{4}$ \\ 1,2,3,4 Universitas Negeri Makassar \\ Makassar, Indonesia \\ ${ }^{*}$ Corresponding author's email: arifuddinm828 [AT] gmail.com
}

\begin{abstract}
The low critical thinking skills of students in fundamental physics courses require an innovative learning model which is the main background in this research. This study aims to (1) know the description of the development of modeling physics learning (2) determine the validity of modeling physics learning to students' critical thinking skills. This type of research is Research and Development with a development model referring to the Wademan and Mckenney model. This research procedure includes preliminary studies, hypothetical model development, model operationalization, and model implementation. Collecting research data using validity assessment techniques and tests of physics competence and critical thinking skills. The data obtained were analyzed by descriptive quantitative. This research shows that (1) Modeling Physics Learning has five phases, namely submission and identification of problems with physical phenomena, provision of prerequisite information, physics modeling, finding solutions, evaluating processes and solutions, (2) The PPF learning model developed in this study is declared feasible because it fulfills the criteria of validity and effectiveness.
\end{abstract}

Keywords--- Physics modeling learning, critical thinking

\section{INTRODUCTION}

Physics is a part of science that has a strategic role in the development of science and technology. Educational reform and integration of 21 st century skills in physics learning needs to be continued. Therefore, teaching physics needs to shift to what students need to do to learn science (Salam, 2018). This condition requires adjustments to the skills needed, namely problem solving, critical thinking, creative thinking, complex decision making which are part of 21st century skills (Khal, 2008) in (Arifuddin et al., 2017).

Critical thinking is a thinking process to analyze arguments and generate insight into each meaning and interpretation, develop reasoning, and understand assumptions. Finally, it can provide a reliable, concise and convincing representation model (Liliasari, 2005). Critical thinking skills are essential in all aspects of life, therefore students really need to be trained to think critically.

Facts in the field based on the results of measuring critical thinking skills of students who program basic physics courses show that the highest score is 35 out of 100 possible scores. This fact indicates the low critical thinking ability and quality of lectures that have been applied so far, therefore it is necessary to apply an innovative learning method, strategy or model.

Physics modeling is an effective way to practice the skills of describing physical phenomena based on the physical facts being observed (Arifuddin, 2009). According to (Alonso \& Finn, 1977) one way of physicists in understanding a physical phenomenon is to use modeling. Observation of the causes of physical events or facts is often difficult to observe so that the application of a model can improve conceptual understanding (Brewe et al., 2010; Dukerich, 2015; Sawtelle et al., 2010).

Considering the suitability of the characteristics of physics learning with physics modeling above, then this can be used as an alternative solution to the problems faced by lecturers and students in basic physics lectures which are still limited to concepts that must be followed up with real implementation in the classroom as an effort to overcome the low ability think critically about students.

\section{LITERATURE REVIEW}

\subsection{Physics Modeling Learning}

Modeling and modeling is an important thing in science (Brewe et al., 2010; Jackson et al., 2008). Physics modeling 
is an effort to understand physics by modeling phenomena from physical phenomena, making image models based on physical phenomena and forming physical equations from phenomena using mathematical formulas and simple physics principles that have been known previously (Arifuddin, 2009; Salam and Arifuddin, 2018).

The modeling stages in physics can consist of modeling physical phenomena, making or observing physical phenomena / phenomena (Chang, et al., 2020); drawing models, making pictures of physical phenomena symptoms based on facts from observations; mathematical models, mathematical reasoning to derive the physics prediction formula (Michelsen, 2015; Liu, C. Y, et al., 2017) ; experimental models, designing experiments to test physics prediction formulas , and carrying out experiments (Danusso et al., 2010).

\subsection{Critical Thinking}

(Santrock, 2011) describes critical thinking as reflective and productive thinking, and involves the evaluation of evidence. (Jensen, 2008) argues that critical thinking means a mental process in pursuit of relevant and correct knowledge about the world. The five main indicators used to observe students' critical thinking skills are detecting problems, collecting data for factual evidence, interpreting images, making interpretations of understanding, definitions, reasoning, and controversial issues, and drawing conclusions from existing and selected data (Wijaya, 2010).

\section{RESEARCH METHODS}

This research is development research to produce a Physics Modeling Learning model that can improve students' critical thinking skills. The development procedure was adapted from Wademan and Mckenney (Plomp \& Nieveen, 2010): a) problem identification, b) identification of tentative products and design principles, c) tentative products and theories, and d) prototyping and assessment of preliminary products and theories.

The subject of this research is the learning model of physics modeling, for the implementation of the learning model students of physics education, computer education, and biology education program students of FKIP ULM are selected to program the Basic Physics course as many as 60 students as test subjects.

Data collection techniques are in the form of assessing the validity of physics modeling learning which is assessed by three validators from physics education experts, and critical thinking skills tests using pre-test and post-test designs. The data from the validity assessment activities were analyzed descriptively qualitatively and the quality of validity refers to the criteria in Table 1.

Table 1. Learning Validity Assessment Criteria

\begin{tabular}{cccc}
\cline { 2 - 3 } & $\begin{array}{c}\text { Score Interval } \\
\text { Rating result }\end{array}$ & $\begin{array}{c}\text { Rating } \\
\text { Category }\end{array}$ & Information \\
\cline { 2 - 4 } & $3.25<$ Score 4.00 & Very Valid & Can be used without revision \\
\hline $2.50<$ Score 3.25 & Valid & Usable with minor revisions \\
\cline { 2 - 3 } Modified from: & (Ress Valid & Can be used with multiple revisions \\
\cline { 2 - 4 } & Ratumanan \& Laurens, 2006) & & Can't be used yet \\
\hline
\end{tabular}

The reliability of the results of the validity of the model can be seen from the interobserver agreement using statistical analysis of Percentage of Agreement (R) (Borich, 2011):

$$
R=\left[1-\left\{\frac{A-B}{A+B}\right\}\right] \times 100 \%
$$

Information:

$\mathrm{R}=$ reliability coefficient of learning model validity

$\mathrm{A}=$ highest score from validator

$\mathrm{B}=$ lowest score from validator

The results of the validity of the learning model are said to be reliable if the percentage of agreement (R) is above $75 \%$ or 0.75 .

Data on critical thinking skills were analyzed using qualitative descriptive statistics and quantitative 
statistics. Normalized gain score analysis is used to see the increase in critical thinking skills. The calculation of the gain score is based on the formula that has been used by (Hake, 1999):

$$
\langle g\rangle=\left(\frac{\%\left\langle S_{f}\right\rangle-\%\left\langle S_{i}\right\rangle}{100 \%-\%\left\langle S_{i}\right\rangle}\right)
$$

Information:

$\langle g\rangle=$ Normalized gain

$\left\langle S_{f}\right\rangle=$ Post-test scores

$\left\langle S_{i}\right\rangle=$ Pre-test score

The results of the data analysis were then consulted in Table 2 to see the improvement of critical thinking skills.

Table 2. Gain Value Reference

\begin{tabular}{cc}
\hline Scale & Criteria \\
\hline$(<g>) \geq 0.7$ & High- $g$ \\
\hline $0.7>(<g>) \geq 0.3$ & medium- $g$ \\
\hline$(<g>)<0.3$ & low- $g$ \\
\hline
\end{tabular}

Source: (Hake, 1999)

\section{RESULTS AND DISCUSSION}

\subsection{Overview of the Development of Physics Modeling Learning (PPF)}

PPF learning model is based on cognitive theory and meaningful learning theory. Based on the learning theory, a learning syntax is made as a series of activities during the learning process which consists of five phases.

The first phase is "proposing and identifying problems with physical phenomena". Problems posed to students can be in the form of problems of physical phenomena that demand a solution. Dewey in (Arends, 1997) encourages teachers to involve students in various problem-oriented projects and helps them investigate various intellectuals, as well as being a stage for motivating students.

The second phase is "providing prerequisite information/knowledge". Providing a rationale for learning certain skills will help motivate (Arends, 1997). The second phase in the PPF model is also based on the concept of an early organizer ( advanced organizer ) of the issues to be studied, providing a structure for new information and connecting it with the information possessed by students (Joyce et al., 2011).

The third phase is "physical modeling". In this phase, students build an appropriate modeling based on the problems they face to build concepts and skills, forming a mental representation of a problem. As they age, their mental representations of the world become more complex and abstract, but the need to understand their environment motivates them to investigate and construct theories/concepts that explain those (Arends, 1997).

The fourth phase of the learning model developed is "finding solutions". In this phase, students are expected both individually and in groups to find solutions after the modeling has been made. A cognitive-constructivist perspective that uses Piaget's opinion that students of any age are actively involved in the process of obtaining information and constructing their own knowledge (Arends, 1997).

The fifth or final phase of learning physics modeling is "process and outcome evaluation". This phase is intended so that the modeling formed by the students and the solutions obtained can be verified. Without feedback, little knowledge is obtained (Arends, 1997).

\subsection{Model Validity}

The hypothetical model developed was validated both content and construct. Validation of the Physics Modeling Learning model was carried out through Focus Group Discussion (FGD) activities. The summary of the results of the validation analysis is shown in Table 3 and the final conclusion given by the validator is valid with minor revisions. 
Table 3. The results of the validation of the Physics Modeling Learning model

\begin{tabular}{cccccc}
\hline No & $\begin{array}{c}\text { Components of } \\
\text { Learning Physics } \\
\text { Modeling }\end{array}$ & $\begin{array}{c}\text { Validation } \\
\text { Score }\end{array}$ & $\begin{array}{c}\text { Validity } \\
\text { Criteria }\end{array}$ & $\begin{array}{c}\text { Reliability } \\
\text { Coefficient }\end{array}$ & $\begin{array}{c}\text { Criteria } \\
\text { Reliability }\end{array}$ \\
\hline 1 & Rational learning model & 3.27 & Very Valid & 0.86 & Reliable \\
\hline 2 & Theory support & 3.40 & Very Valid & 0.86 & Reliable \\
\hline 3 & Model syntax & 3.52 & Very Valid & 0.84 & Reliable \\
\hline 4 & Social system & 3.61 & Very Valid & 0.86 & Reliable \\
\hline 5 & Reaction principle & 3.42 & Very Valid & 0.81 & Reliable \\
\hline 6 & Support system & 3.52 & Very Valid & 0.85 & Reliable \\
\hline 7 & $\begin{array}{c}\text { Instructional impact and } \\
\text { accompaniment }\end{array}$ & 3.60 & Very Valid & 0.86 & Reliable \\
\hline 8 & Average & 3.48 & Very Valid & 0.87 & Reliable \\
\hline
\end{tabular}

Table 3 shows the reliability coefficient of Physics Modeling Learning is above the provisions of the inter observer agreement, which is 0.75 (Borich, 2011). So it can be said that all of the items contained in the validation sheet instrument for Physics Modeling Learning are in the reliable category.

The results of the expert assessment indicate that the PPF model is in the valid category, both in terms of content and constructs. Valid Physics Modeling Learning means having several characteristics, namely the existence of conformity with needs, novelty (state of art). (Plomp \& Nieveen, 2010) states that the learning model is said to be valid if it meets the criteria of being valid in content and valid in constructs. Content valid means there is an element of novelty (state-of-theart) and constructively valid means there is consistency between parts of the model and there is consistency between the developed models and the learning theories that underlie them. The novelty of the PPF learning model is related to $21 \mathrm{st}$ century skills, namely critical thinking. The PPF learning model is content valid because it can be used to anticipate various demands/needs for 21 st century skills that must be possessed by students.

The PPF model has shown consistency between phases in the model syntax. The PPF model consists of five phases, namely 1) Submission and identification of physical phenomena problems, 2) Provision of prerequisite information/knowledge, 3) Physics modeling, 4) Finding solutions, and 5) Evaluation of processes and results. The five phases have been designed to be interrelated with each other. The relationship between phases in the PPF model syntax can be explained as follows. To focus attention and interest so that it is necessary to clarify goals and provide initial information as a basis for solving problems. Then the stage of submitting the phenomenon to stimulate the construction of knowledge and motivation, then continued with the stage of physics modeling to demonstrate the ability of mental representation to solve problems, then look for solutions independently and the final stage is evaluating the process and results as feedback so that the right knowledge and solutions are obtained to the problems posed.

The PPF model developed in this study is included in the valid category, both in terms of content and constructs, so it can be used as a guide in planning for teaching physics and training in reasoning and solving physics problems. This is in line with the statement of (Seechaliao et al., 2012) that a valid learning model can help researchers and practitioners in designing learning because it is constructed from learning principles that have been understood.

\subsection{Model Implementation}

Table 4. Summary of Critical Thinking Skills Test Results Score

\begin{tabular}{|c|c|c|c|c|c|c|}
\hline \multirow{2}{*}{ Information } & \multicolumn{2}{|c|}{ First class } & \multicolumn{2}{|c|}{ Second Class } & \multicolumn{2}{|c|}{ Third Class } \\
\hline & $\begin{array}{c}\text { Pre- } \\
\text { Test }\end{array}$ & $\begin{array}{c}\text { Post- } \\
\text { Test }\end{array}$ & $\begin{array}{l}\text { Pre- } \\
\text { Test }\end{array}$ & $\begin{array}{c}\text { Post- } \\
\text { Test }\end{array}$ & $\begin{array}{c}\text { Pre- } \\
\text { Test }\end{array}$ & $\begin{array}{c}\text { Post- } \\
\text { Test }\end{array}$ \\
\hline The highest score & 25 & 85 & 30 & 85 & 35 & 85 \\
\hline Lowest Value & 5 & 65 & 10 & 75 & 10 & 75 \\
\hline Ideal Value & 100 & 100 & 100 & 100 & 100 & 100 \\
\hline Average & 13.33 & 77.27 & 16.67 & 80,90 & 20.0 & 71.1 \\
\hline$N$-gain average & \multicolumn{2}{|c|}{0.73} & \multicolumn{2}{|c|}{0.77} & \multicolumn{2}{|c|}{0.725} \\
\hline$N$-gain low category & \multicolumn{2}{|c|}{$0 \%$} & \multicolumn{2}{|c|}{$0 \%$} & \multicolumn{2}{|c|}{$0 \%$} \\
\hline$N$-gain medium category & \multicolumn{2}{|c|}{$11.11 \%$} & \multicolumn{2}{|c|}{$0 \%$} & \multicolumn{2}{|c|}{$38.5 \%$} \\
\hline$N$-gain high category & \multicolumn{2}{|c|}{$88.89 \%$} & \multicolumn{2}{|c|}{$100 \%$} & \multicolumn{2}{|c|}{$61.5 \%$} \\
\hline
\end{tabular}


The results of model implementation have an effect on students' critical thinking skills. Based on the results of tests conducted on students, a summary of the results of the analysis of students' critical thinking is shown in Table 4 .

The results of the students' critical thinking skills test for the three implementation classes are shown in Table 4 . With an ideal value of 100 , for the first class the increase in the average value from 13.33 to 77.27 with an average n-gain value of 0.73 means the improvement of students' critical thinking skills for the first class is in the high category. For the second class the increase in the average value from 16.67 to 80.90 with an average n-gain value of 0.77 means that the increase in students' critical thinking skills for the second class is in the high category. For the third class, the increase in the average value from 20.0 to 78.0 with an average n-gain value of 0.725 means that the increase in students' critical thinking skills for the third class is in the high category. To see the consistency of improving critical thinking skills from the implementation of the learning model for the three classes, it can be seen from the results of the $\mathrm{N}$-gain test that all classes are in the high category.

The consistency of the results of critical thinking skills is caused by the implementation of the PPF learning model syntax for each learning phase which is carried out very well, as well as student activities that are relevant to activities in each phase of the PPF learning model. This is in accordance with the results of research by (Koellner-Clark \& Lesh, 2003) which shows that critical thinking skills are not an automatic result of natural growth and development but need to be taught or trained.

\section{CONCLUSION}

Based on the results of research and discussion, the following conclusions are obtained: Physics Modeling Learning has five phases, namely submission and identification of physical phenomena problems, provision of prerequisite information, physics modeling, finding solutions, evaluating processes and solutions; The PPF learning model developed in this study was declared to have met the criteria of validity and effectiveness.

\section{REFERENCES}

[1] Alonso, M., \& Finn, E. J. (1977). Fundamental University Physics: Vol. 1st Volume. Addison-Wesley Publisher.

[2] Arends, R. I. (1997). Classroom Instruction and Management. McGraw-Hill Companies.

[3] Arifuddin, M. (2009). Development of Mechanical Physics Modeling Through the Direct Teaching Basic Physics Class. Universitas Negeri Surabaya.

[4] Arifuddin, M., Mastuang, M., \& Mahardika, A. I. (2017). Improving Problem Solving Skill in Physics Through Argumentation Strategy in Direct Instruction Model. International Journal of Sciences: Basic and Applied Research (IJSBAR), 35(3), 348-353.

[5] Borich, G. D. (2011). Observation Skills for Effective Teaching (6th Edition). Pearson.

[6] Brewe, E., Sawtelle, V., Kramer, L. H., O’Brien, G. E., Rodriguez, I., \& Pamelá, P. (2010). Toward equity through participation in Modeling Instruction in introductory university physics. Physical Review Special Topics - Physics Education Research, 6(1), 010106. https://doi.org/10.1103/PhysRevSTPER.6.010106

[7] Danusso, L., Testa, I., \& Vicentini, M. (2010). Improving Prospective Teachers' Knowledge about Scientific Models and Modelling: Design and Evaluation of a Teacher Education Intervention. International Journal of Science Education, 32(7), 871-905.

[8] Dukerich, L. (2015). Applying Modeling Instruction to High School Chemistry To Improve Students' Conceptual Understanding. Journal of Chemical Education, 92(8), 1315-1319. https://doi.org/10.1021/ed500909w

[9] Hake, R. R. (1999). ANALYZING CHANGE/GAIN SCORES*. American Educational Research Association's Division D, Measurement and Research Methodology.

[10] Jackson, J., Dukerich, L., \& Hestenes, D. (2008). Modeling Instruction: An Effective Model for Science Education. Science Educator, 17(1), 8.

[11] Jensen, E. (2008). Brain-Based Learning. Student Library.

[12] Joyce, B., Weil, M., \& Calhoun, E. (2011). Models of Teaching: Model-Model Pengajaran (8th Ed). Pustaka Pelajar.

[13] Koellner-Clark, K., \& Lesh, R. (2003). Whodunit? Exploring Proportional Reasoning through the Footprint Problem. School Science and Mathematics, 103(2), 92-98. https://doi.org/10.1111/j.1949-8594.2003.tb18224.x

[14] Liliasari. (2005). Membangun Keterampilan Berpikir Manusia Indonesia Melalui Pendidikan Sains. Pidato Pengukuhan Guru Besar dalam Pendidikan http://staffnew.uny.ac.id/upload/132319972/penelitian/Prosiding\%20Seminar\%20Nasional\%20IPA\%20III\%20tahun $\% 202011 . p d f$

[15] Plomp, T., \& Nieveen, N. M. (2010). An introduction to educational design research: Proceedings of the seminar conducted at the East China Normal University, Shanghai (PR China), November 23-26, 2007. http://www.slo.nl/downloads/2009/Introduction_20to_20education_20design_20research.pdf/download 
[16] Ratumanan, T., \& Laurens, T. (2006). Evaluasi Hasil belajar yang relevan dengan kurikulum berbasis kompetensi. Unesa University Press.

[17] Salam, A. (2018). Teknik Pemodelan Fisika dalam Setting Pembelajaran Berbasis Learner Autonomy. Jurnal Fisika FLUX, 15, 47. https://doi.org/10.20527/flux.v15i1.4472

[18] Santrock, J. W. (2011). Educational Psychology. Kencana.

[19] Sawtelle, V., Brewe, E., \& Kramer, L. H. (2010). Positive Impacts of Modeling Instruction on Self-Efficacy. AIP Conference Proceedings, 1289(1), 289-292. https://doi.org/10.1063/1.3515225

[20] Seechaliao, T., Natakuatoong, O., \& Wannasuphoprasit, W. (2012). The Validation of an Instructional Design and Development Model Based on Engineering Creative Problem Solving Principles to Develop Creative Thinking Skills of Undergraduate Engineering Students. 30, 9.

[21] Wijaya, C. (2010). Pendidikan Remedial: Sarana Pengembangan Mutu Sumber Daya Manusia. PT. Remaja Rosda Karya. 